\title{
Carbazole Electroactive Amorphous Molecular Material: Molecular Design, Synthesis, Characterization and Application in Perovskite Solar Cells
}

\author{
Diego Magaldi ${ }^{1}$, Maria Ulfa ${ }^{2}$, Sébastien Péralta ${ }^{1}$, Fabrice Goubard ${ }^{1} \mathbb{1}$, Thierry Pauporté ${ }^{2, *}$ and \\ Thanh-Tuân Bui ${ }^{1, *(D)}$ \\ 1 LPPI, CY Cergy Paris Université, F-95,000 Cergy, France; diegomagaldi@outlook.com (D.M.); \\ sebastien.peralta@cyu.fr (S.P.); fabrice.goubard@cyu.fr (F.G.) \\ 2 Chimie ParisTech, PSL Research University, CNRS, Institut de Recherche de Chimie Paris (IRCP), 11 rue P. et \\ M. Curie, F-75,005 Paris, France; maria.ulfa@chimieparistech.psl.eu \\ * Correspondence: thierry.pauporte@chimieparistech.psl.eu (T.P.); tbui@cyu.fr (T.-T.B.)
}

Received: 1 April 2020; Accepted: 3 June 2020; Published: 5 June 2020

\begin{abstract}
In perovskite photovoltaics (PSCs), the role of the hole transporting material (HTM) is highly important as it significantly influents to the global device's performance and stability. Hole transporter ensures the extraction of hole at the perovskite/HTM interface and transport it towards the cathode. Thus, accurate molecular design affording to efficient and cost-effective HTM is of major interest. Small molecules having glass forming property is an attractive class as it can form morphologically stable thin film. Herein, a carbazole molecular glass bearing a polymerizable function was designed and synthetized. Its characteristics are suitable for application as HTM in PSCs. The preliminary photovoltaic application lead to device efficiency of $14-15 \%$ depending on the chemical composition of the perovskite employed. These promising results open the way to design new alternative molecular and polymeric HTMs suitable for solution processed hybrid solar cells.
\end{abstract}

Keywords: molecular glass; hole transporting material; perovskite solar cell; hybrid photovoltaics; carbazole; arylamine

\section{Introduction}

In perovskite photovoltaics (PSCs), the active component generally compose of a perovskite (PVK) layer sandwiched between two charge transport layers of different nature made from a hole (HTM) and an electron (ETM) transporting materials, respectively [1]. The HTM plays an important role as it extracts hole at the hole transporting layer/PVK interface and transport them towards the cathode [2]. HTMs are thus designed to have high charge transport capacity and suitable HOMO and LUMO energy levels ( $\mathrm{E}_{\mathrm{HOMO}} \& \mathrm{E}_{\mathrm{LUMO}}$ ) being compatible with that of the perovskite material. This provides suitable driving force for charge transfer at the HTM/PVK interfaces and block the back electron transfer. Other researched characteristics include excellent thermal and photochemical stability, amorphous homogeneous thin film forming capacity and high hydrophobic nature to protect the perovskite from moisture [3]. Huge research effort was done to the development of molecular HTMs for hybrid photovoltaic devices, including PSCs [4,5]. In solid state, small molecules tend to crystallize. So fabrication of their amorphous thin film stable above ambient temperature required meticulously engineered small conjugated molecules [6]. Among the different HTM families (such as thiophene [7], fused thiophene [8,9], furan [10], acridine [11], trizatruxenes [12], etc.) carbazole derivatives occupy an important place thanks to their unique properties $[13,14]$. We have shown that 
carbazole is an excellent platform to design not only HTMs for solid-state dye-sensitized solar cells (DSSCs) [15] and PSCs [16-19] but also as photoinitiators for photopolymerization and 3D printing technique [20-23]. Herein, we prepare a novel molecular glass denoted as iDM1 (Scheme 1) and test it as HTM in PSCs.<smiles>C=Cc1ccc(Cn2c3cc(N(c4ccc(OC)cc4)c4ccc(OC)cc4)ccc3c3ccc(N(c4ccc(OC)cc4)c4ccc(OC)cc4)cc32)cc1</smiles>

Scheme 1. Molecular structure of the novel molecular glass (iDM1).

In iDM1 structure the carbazole core bears two di(4-methoxyphenyl)aminyl moieties, which is commonly used in combination with carbazole to construct HTMs [13]. at its 2,7 positions. The methoxy group plays an important role in designing hole transporters: it effectively tunes the solubility as well as the optical and electrochemical properties of targeted molecules [24]. On the other hand, it provides a good interaction with the perovskite surface [25]. The 4-vinylbenzyl chain at the 9-position of the carbazole offer the possibility of transforming iDM1 into its corresponding polymer for a possibly monomer vs. polymer comparative study [17].

\section{Materials and Methods}

\subsection{Synthesis and Characterization of the Hole Transporting Material}

The general conditions for the chemical synthesis, the structural analysis and the investigation of the iDM1's thermal, morphologic, photo-physical and electrochemical characteristics were done following our previously well-established procedure [18]. Scheme 2 illustrates different step of the synthesis of the targeted molecule iDM1. Briefly, 2,7-dibromocarbazole was prepared in suitable yield in two steps from 4,4'-dibromobiphenyl following literature procedure [26]. It was then subjected to a $N$-benzylation reaction in strong basic medium affording the 2,7-dibromo-9-(4-vinylbenzyl)-2,7-dibromocarbazole.
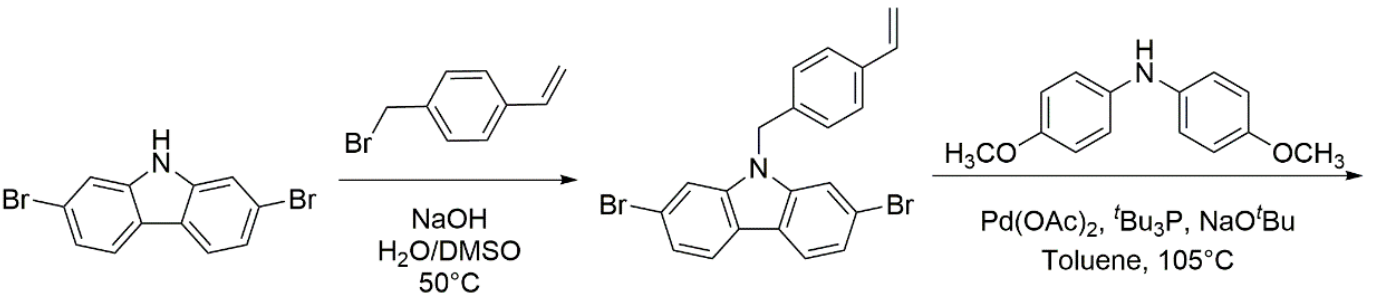

iDM1

Scheme 2. Synthesis of iDM1.

Subsequently, the later was engaged in a twofold Pd-catalyzed Buchwald-Hartwig amination with di(4-methoxyphenyl)amine affording to iDM1 as a yellowish powder after purification.

Synthesis of iDM1: In a dry 100-mL round-bottom flask, 2,7-dibromocarbazole (195 mg, $0.6 \mathrm{mmol}$ ), 4-vinylbenzyl bromide (177 mg, $0.9 \mathrm{mmol}), \mathrm{NaOH}(190 \mathrm{mg}, 4.7 \mathrm{mmol}$, dissolved in $1 \mathrm{~mL}$ of water) and DMSO $(6 \mathrm{~mL})$ were charged. The mixture was heated to $50{ }^{\circ} \mathrm{C}$ for $4 \mathrm{~h}$ and allowed to cool to room temperature. The reaction mixture was quenched with brine $(10 \mathrm{~mL})$ and extracted with $\mathrm{CH}_{2} \mathrm{Cl}_{2}$ $(3 \times 15 \mathrm{~mL})$. The organic layers were combined, washed with brine and water, dried over anhydrous $\mathrm{MgSO}_{4}$, filtered and concentrated under reduced pressure. The crude product was purified by column chromatography eluting with $\mathrm{CH}_{2} \mathrm{Cl}_{2} /$ petroleum ether ( $\left.4 / 6 \mathrm{v} / \mathrm{v}\right)$ to yield a white solid ( $160 \mathrm{mg}, 85 \%$ yield). 
The compound was directly engaged in the next step without further characterization. In an oven-dried Schlenk under argon stream, the freshly prepared $N$-(4-vinylbenzyl)-2,7-dibromocarbazole (311 mg, $1.0 \mathrm{mmol}), 4,4^{\prime}$-dimethoxydiphenylamine ( $\left.688 \mathrm{mg}, 3.0 \mathrm{mmol}\right)$, palladium(II) acetate $(12 \mathrm{mg}, 0.05 \mathrm{mmol})$, sodium tert-butoxide (384 mg, $4.0 \mathrm{mmol})$, tri-tert-butyl phosphine $(20 \mathrm{mg}, 0.1 \mathrm{mmol}$, dissolved in $1 \mathrm{~mL}$ of distilled toluene) and freshly distilled toluene $(10 \mathrm{~mL})$ were charged. The septum-sealed Schlenk system was vacuum purged and then argon refilled. This procedure was repeated five times. The mixture was stirred under an argon atmosphere in sealed Schlenk tubes at $105{ }^{\circ} \mathrm{C}$ for $80 \mathrm{~h}$ and allowed to cool to room temperature. The reaction mixture was diluted with ethyl acetate $(75 \mathrm{~mL})$ and washed with water $(3 \times 100 \mathrm{~mL})$ and brine $(1 \times 50 \mathrm{~mL})$, dried over anhydrous $\mathrm{MgSO}_{4}$, filtered and concentrated under reduced pressure. This crude product was subjected to a fast column chromatography separation eluting with $\mathrm{CH}_{2} \mathrm{Cl}_{2}$. The collected fractions were combined, and solvent was removed under vacuum to give a viscous oil which was added to methanol $(200 \mathrm{~mL})$ with vigorous stirring. The precipitate was then filtered, rinsed with methanol several times. The final purification was done by silica gel chromatography eluting with hexane/ethyl acetate $(4 / 1 \mathrm{v} / \mathrm{v})$ affording a yellowish solid (500 mg, 68\% yield). ${ }^{1} \mathrm{H}$ NMR $\left(250 \mathrm{MHz}, \mathrm{DMSO}_{-} \mathrm{d}_{6}\right) \delta(\mathrm{ppm}) 7.78(\mathrm{~d}, 2 \mathrm{H}, J=8.37 \mathrm{~Hz}), 7.31(\mathrm{~d}, 2 \mathrm{H}$, $J=8.22 \mathrm{~Hz}), 6.94(\mathrm{~d}, 10 \mathrm{H}, J=9.0 \mathrm{~Hz}), 6.84(\mathrm{~d}, 10 \mathrm{H}, J=9.17 \mathrm{~Hz}), 6.73(\mathrm{~m}, 1 \mathrm{H}), 6.65(\mathrm{~d}, 2 \mathrm{H}, J=8.37 \mathrm{~Hz})$, $5.79(\mathrm{~d}, 1 \mathrm{H}, J=17.69 \mathrm{~Hz}), 5.25(\mathrm{~d}, 1 \mathrm{H}, J=15.64 \mathrm{~Hz}), 5.19(\mathrm{~s}, 2 \mathrm{H}), 3.72(\mathrm{~s}, 12 \mathrm{H}) .{ }^{13} \mathrm{C}$ NMR $(62.5 \mathrm{MHz}$, DMSO-d $_{6}$ ); $\delta$ (ppm) 155.1, 146.0, 141.4, 141.0, 137.0, 136.2, 136.1, 127.2, 126.2, 125.35, 120.4, 117.5, 115.2, 114.8, 114.7, 102.6, 82.0, 55.6. HR-MS (ESI+): calculated for $[\mathrm{M}+\mathrm{H}]^{+}:$738.3326/found 738.3311.

\subsection{Preparation and Characterization of Perouskite Solar Cells}

The different steps for preparing perovskite photovoltaic devices (substrate etching, cleaning and preparation of $\mathrm{FTO} / b l-\mathrm{TiO}_{2} /$ meso- $\mathrm{TiO}_{2}$ layer, preparation and deposition of the hole transporting layer, thermal evaporation of gold back electrode and $\mathrm{J}-\mathrm{V}$ characterizations) were followed from our previous optimized procedure [17-19,27]. In this work, different perovskite layers, named MAPI(2), MAPI(1)-SOF and FAMA were elaborated by two-step sequential and one-step deposition techniques by spin coating. The detailed procedure for each perovskite is detailed below.

\section{Preparation of Different Perovskite Layers}

MAPI(2): This $\mathrm{CH}_{3} \mathrm{NH}_{3} \mathrm{PbI}_{3}$ perovskite was made by a 2-step sequential deposition method.

Step 1: $\mathrm{PbI}_{2}(461 \mathrm{mg})$ was dissolved in dried $N, N$-dimethylformamide $(1 \mathrm{~mL})$ and stirred at $70{ }^{\circ} \mathrm{C}$ for $20 \mathrm{~min}$ until full dissolution. Then, concentrated $37 \% \mathrm{HCl}(30 \mu \mathrm{L})$ were added. $50 \mu \mathrm{L}$ of this solution was spin-coated ( $4000 \mathrm{rpm} / \mathrm{s}, 4000 \mathrm{rpm}, 30 \mathrm{~s}$ ) on top of the oxide electron transport layer.

Step 2: methylammonium iodide (MAI, $40 \mathrm{mg}$ ) was dissolved in 2-propanol (1 mL). $100 \mu \mathrm{L}$ of this solution was dropped on top of $\mathrm{PbI}_{2}$ layer and wait for $20 \mathrm{~s}$ before starting the spinning $(4000 \mathrm{rpm} / \mathrm{s}$, $4000 \mathrm{rpm}, 30 \mathrm{~s}$ ). The sample was subsequently annealed at $115^{\circ} \mathrm{C}$ for $1 \mathrm{~h}$ to form a dark-brown perovskite layer.

MAPI(1)-SOF: The preparation of this $\mathrm{CH}_{3} \mathrm{NH}_{3} \mathrm{PbI}_{3}$ perovskite layer was inspired from the work of Park et al. [28], for which the precursors $\left(\mathrm{PbI}_{2}\right.$ and MAI in 1:1 molar ratio) were dissolved in a mixed DMF and DMSO solvent. $\mathrm{PbI}_{2}(461 \mathrm{mg})$ and MAI $(159 \mathrm{mg})$ were dissolved in a mixture of DMF $(723 \mu \mathrm{L})$ and of DMSO $(81 \mu \mathrm{L}) .45 \mu \mathrm{L}$ of this solution was then deposited onto the ETM layer by using a two-step spin-coating program: (1) spinning at $1000 \mathrm{rpm}$ for $10 \mathrm{~s}$ and (2) then at $4000 \mathrm{rpm}$ for $20 \mathrm{~s}$. At $7 \mathrm{~s}$ of the second step spinning program, chlorobenzene $(110 \mu \mathrm{L})$ was slowly dripped onto the rotating substrate before the surface changed to turbid due to the rapid vaporization of DMF. The obtained film was then heated at $105^{\circ} \mathrm{C}$ for $1 \mathrm{~h}$ on a hotplate.

FAMA is a mixed cation and mixed anion perovskite with the composition of $\mathrm{FA}_{0.87} \mathrm{MA}_{0.13}$ $\mathrm{Pb}\left(\mathrm{I}_{0.87} \mathrm{Br}_{0.17}\right)_{3}\left(\mathrm{FA}^{+}\right.$being the formamidinium cation). Its preparation was reported in our previous work [19] from the precursor solution containing 1-M FAI, 0.2-M MABr, 1.1-M $\mathrm{PbI}_{2}$ and 0.22-M $\mathrm{PbBr}_{2}$ in a mixture of DMF and DMSO (4:1 volume ratio). This solution $(45 \mu \mathrm{L})$ was the spin-coated on the top of $\mathrm{FTO} / b l-\mathrm{TiO}_{2} /$ meso- $\mathrm{TiO}_{2}$ substrate using a 2-step spin-coating program (step 1: $1000 \mathrm{rpm}$, 
$200 \mathrm{rpm} / \mathrm{s}, 20 \mathrm{~s}$; step 2: $6000 \mathrm{rpm}, 3000 \mathrm{rpm} / \mathrm{s}, 30 \mathrm{~s}$ and after $20 \mathrm{~s}$, chlorobenzene $(100 \mu \mathrm{L})$ was dripped on the sample). The obtained film was immediately annealed at $100{ }^{\circ} \mathrm{C}$ for $1 \mathrm{~h}$.

\section{Results and Discussion}

\subsection{Thermal Properties}

Thermogravimetric analysis (TGA, Figure 1a) shown that iDM1 has high thermal stability with decomposition temperature $\left(\mathrm{T}_{\mathrm{d}}\right)$ of $425^{\circ} \mathrm{C}$, which ensures the stability of the molecule below $400{ }^{\circ} \mathrm{C}$. The molecule is thus thermally stable enough for optoelectronic and photovoltaic applications $[29,30]$.

(a)

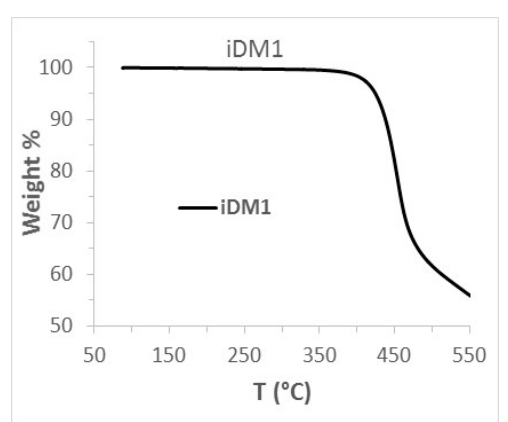

(c)

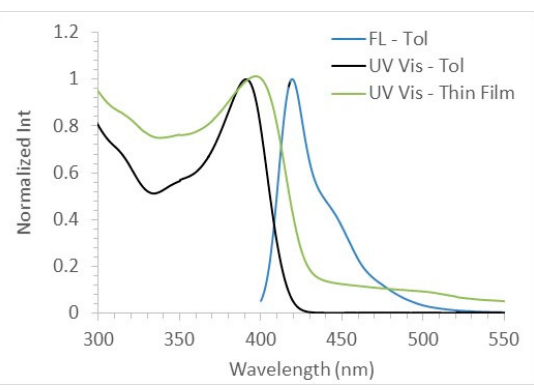

(b)

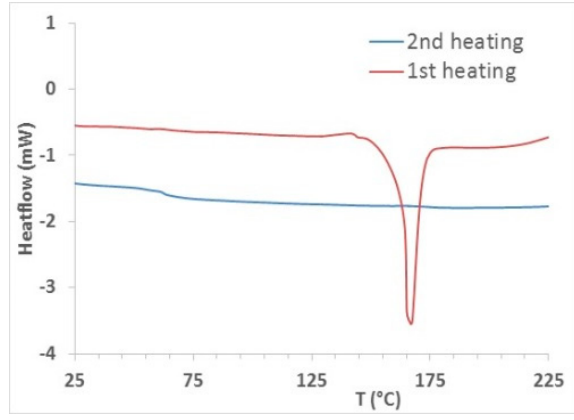

(d)

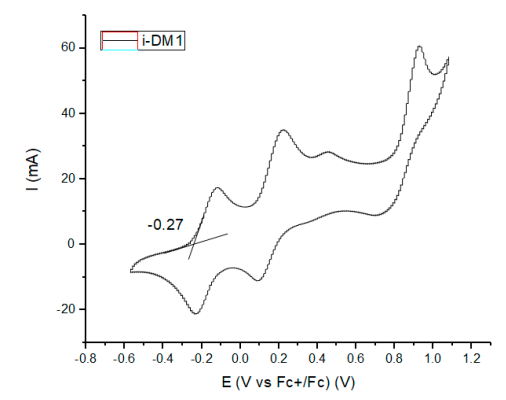

Figure 1. Thermogravimetric analysis (TGA) (a,b) differential scanning calorimetry analysis (DSC) curves, (c) absorption and photoluminescence spectra and (d) cyclic voltammogram of iDM1.

The differential scanning calorimetry analysis (DSC, Figure $1 \mathrm{~b}$ ) revealed the glass forming property of iDM1. During the first heating scan iDM1 showed a sharp and intense endothermic transition centered at $166.7^{\circ} \mathrm{C}$, which is attributed to its melting point $\left(\mathrm{T}_{\mathrm{m}}\right)$. On the second one, only the glass transition was recorded at the glass transition's temperature $\left(\mathrm{T}_{\mathrm{g}}\right)$ of $62.5^{\circ} \mathrm{C}$. This value is slightly higher than that of its 3,6-isomer reported earlier $\left(\mathrm{T}_{\mathrm{g}}=61^{\circ} \mathrm{C}\right)$ [17] due to its higher steric hindrance of the 2,7-disubstituted molecule.

\subsection{Optical Properties}

In dilute solution, iDM1 mostly absorbs in the UV region and poorly absorbs in the visible spectral domain with the maximum absorption centered at the wavelength $\lambda_{\max }=391 \mathrm{~nm}$ (Figure 1c). This characteristic can make iDM1 a promising photoinitiator for light emitting diode induced photopolymerization [31]. Additionally, this avoids competitive absorption with light absorber when applied as HTM in hybrid solar cells. In solution, iDM1 photoluminescence is centered at the wavelength of $419 \mathrm{~nm}$. A Stock shift of $28 \mathrm{~nm}$ was recorded, which is somehow smaller than that of its 3,6-isomer reported earlier [17]. In thin film, the absorption slightly redshifts to $397 \mathrm{~nm}$, due to the steric hindrance of iDM1 avoiding molecular aggregation in the solid state. The optical bandgap $(\mathrm{Eg}=2.85 \mathrm{eV}$ ), calculated from the absorption onset of the thin film (Figure 1c, $435 \mathrm{~nm}$ ), is somewhat close to that of its 3,6-isomer [17] and Spiro-OMeTAD [15]. 


\subsection{Electrochemical Properties}

iDM1's cyclic voltammogram (Figure 1d) shows multiple oxidation processes due to the presence of multiple electron-rich tertiary amine moieties in its structures. The first quasi-reversible oxidation at low potential is attributed to oxidation of the carbazole moiety to form the corresponding radical cation. The onset potential of this oxidation is $-0.27 \mathrm{~V} / \mathrm{Fc} / \mathrm{Fc}^{+}$, which is lower than that of Spiro-OMeTAD $\left(-0.11 \mathrm{~V} / \mathrm{Fc} / \mathrm{Fc}^{+}\right)$[15]. The corresponding energy level of its HOMO orbital ( $\left.\mathrm{E}_{\mathrm{HOMO}}\right)$ was estimated from this potential by taking the ionization energy of ferrocene ( $4.8 \mathrm{eV}$ vs. vacuum) as the standard. Its $\mathrm{E}_{\mathrm{LUMO}}$ was then estimated from the $\mathrm{E}_{\mathrm{HOMO}}$ and $\mathrm{Eg}$. The $\mathrm{E}_{\mathrm{HOMO}}$ values of iDM1 and Spiro-OMeTAD are $-4.53 \mathrm{eV}$ and $-4.69 \mathrm{eV}$, respectively. Actually, $\mathrm{E}_{\mathrm{HOMO}}$ of $\mathrm{iDM1}$ is slightly higher than that of Spiro-OMeTAD. The corresponding $\mathrm{E}_{\mathrm{LUMO}}$ are very close and are -1.68 and $-1.69 \mathrm{eV}$, respectively. This suggests that, energetically, iDM1 could be suitable as an alternative HTM to Spiro-OMeTAD.

\subsection{Photovoltaic Application}

The photovoltaic property of iDM1 was studied in classic PSC architecture $\left(\mathrm{FTO} / b l-\mathrm{TiO}_{2} /\right.$ meso- $-\mathrm{TiO}_{2} /$ Perovskite/HTM/Au) [32], using different perovskite composition and deposition methods. Figure 2 illustrates the different solar cell's layer and their energy alignment. The composition of the hole transporting layer is also shown.
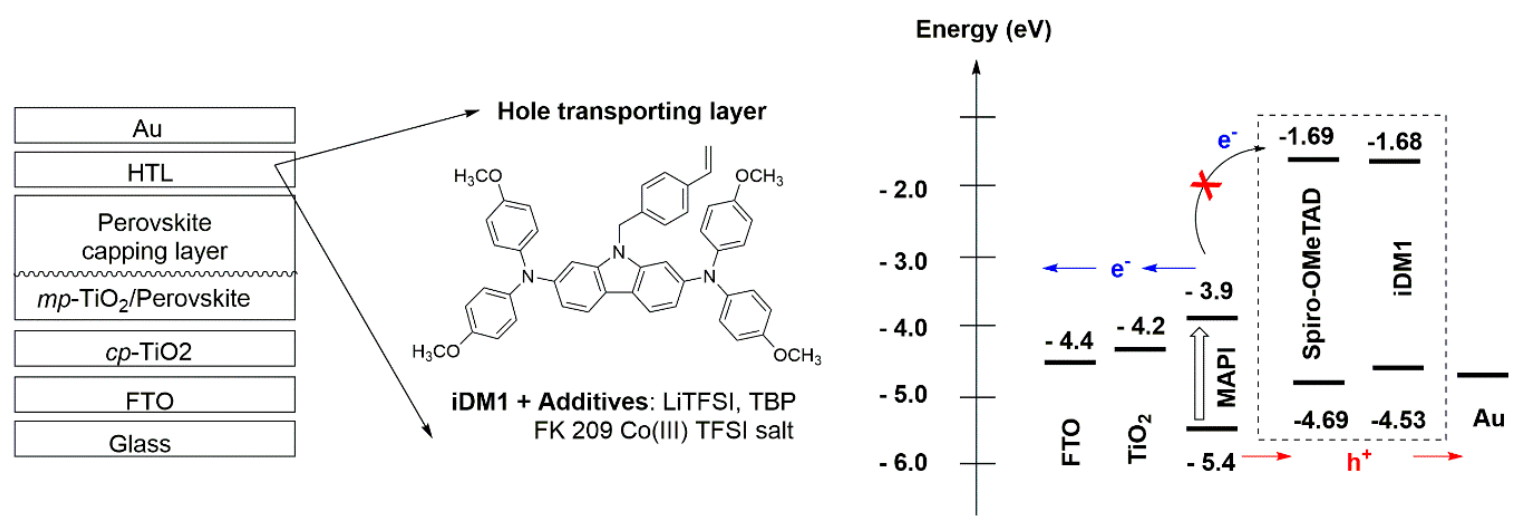

Figure 2. Perovskite device structure and energy alignment of different device component.

In this work, the photovoltaic device was made on FTO/glass substrate and composed of a thin compact blocking- $\mathrm{TiO}_{2}$ layer, a mesoporous $\mathrm{TiO}_{2}$ layer filled and capped with the perovskite absorber of different compositions, a hole transporting layer. Finally, a thin gold metal layer was thermally deposited to serve as device back contact. MAPI(2) denotes the $\mathrm{CH}_{3} \mathrm{NH}_{3} \mathrm{PbI}_{3}$ perovskite made by 2-step sequential spin coating deposition while MAPI(1)-SOF was made by 1-step spin-coating technique from a mixture of DMF/DMSO solvent. FAMA denotes the mixed cation mixed anion perovskite $\mathrm{FA}_{0.87} \mathrm{MA}_{0.13} \mathrm{~Pb}\left(\mathrm{I}_{0.87} \mathrm{Br}_{0.17}\right)_{3}$ [33]. The thickness of the carbazole-based hole transport layer is ca. $200 \mathrm{~nm}$ while that made from Spiro-OMeTAD is ca. $150 \mathrm{~nm}$ of [19]. The photocurrent/voltage graphs of the best cells are displayed in Figure 3 and the photovoltaic characteristics are summarized in Table 1. 

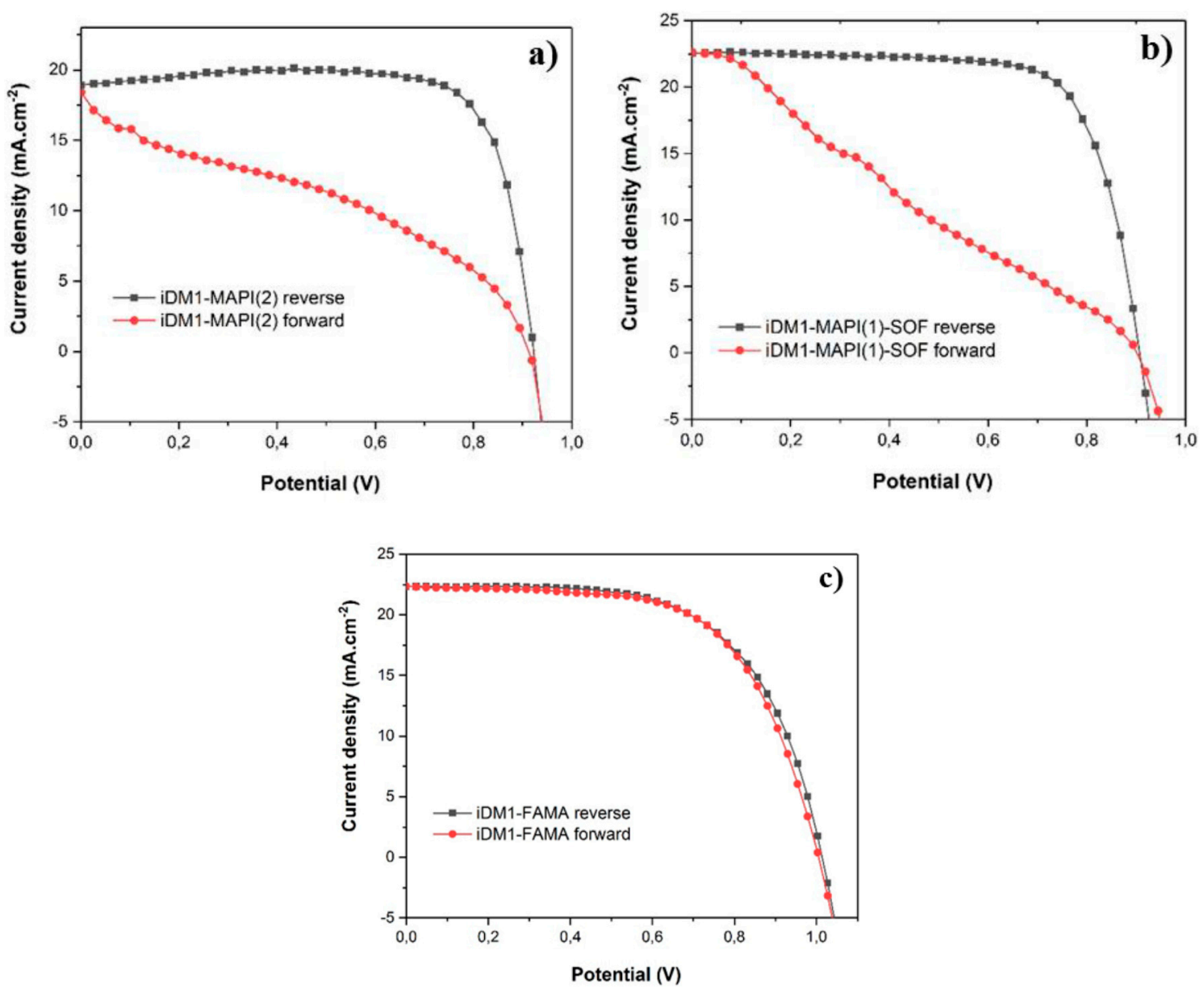

Figure 3. $J-V$ curves of the best iDM1 based perovskite photovoltaics (PSCs) made from (a) MAPI(2), (b) MAPI(1)-SOF and (c) FAMA perovskites.

Table 1. Best and average (values given in parenthesis) photovoltaic parameters of iDM1 cells prepared with different perovskite (MAPI(2), MAPI(1)-SOF and FAMA). The performance of Spiro-OMeTAD based perovskite photovoltaics (PSCs) were taken from our previous report for comparison purpose.

\begin{tabular}{|c|c|c|c|c|c|c|}
\hline HTM-Perovskite & $\begin{array}{c}\text { Scan } \\
\text { Direction }\end{array}$ & $\mathrm{V}_{\mathrm{OC}}(\mathrm{V})$ & $\begin{array}{c}\text { JSC } \\
\left(\mathrm{mA} \cdot \mathrm{cm}^{-2}\right)\end{array}$ & FF (\%) & PCE (\%) & Ref. \\
\hline \multirow{2}{*}{ iDM1-MAPI(2) } & Reverse & $0.92(0.91)$ & $18.92(18.80)$ & $80.78(77.28)$ & $14.10(13.29)$ & \multirow{2}{*}{ This work } \\
\hline & Forward & $0.91(0.91)$ & $17.90(17.93)$ & $36.11(34.45)$ & $5.90(5.60)$ & \\
\hline \multirow{2}{*}{ iDM1-MAPI(1)-SOF } & Reverse & $0.91(0.92)$ & $22.59(22.05)$ & $73.40(70.63)$ & $15.04(14.28)$ & \multirow{2}{*}{ This work } \\
\hline & Forward & $0.89(0.88)$ & $22.60(22.08)$ & $25.57(23.85)$ & $5.12(4.62)$ & \\
\hline \multirow{2}{*}{ iDM1-FAMA } & Reverse & $1.01(1.02)$ & $22.33(21.94)$ & $62.06(62.42)$ & $14.04(13.95)$ & \multirow{2}{*}{ This work } \\
\hline & Forward & $1.00(1.01)$ & $22.32(21.91)$ & $62.49(61.96)$ & $14.01(13.69)$ & \\
\hline \multirow{2}{*}{ Spiro-OMeTAD-MAPI } & Reverse & $1.01(1.01)$ & $22.15(20.83)$ & $78.75(76.50)$ & $17.68(16.10)$ & \multirow{2}{*}{ [33] } \\
\hline & Forward & $1.00(0.99)$ & $22.72(21.02)$ & $63.02(59.30)$ & $14.45(12.42)$ & \\
\hline \multirow{2}{*}{ Spiro-OMeTAD—FAMA } & Reverse & $1.02(1.01)$ & $24.05(23.34)$ & $76.10(75.93)$ & $18.67(17.93)$ & \multirow{2}{*}{ [33] } \\
\hline & Forward & $1.01(0.99)$ & $23.24(23.27)$ & $55.02(50.72)$ & $12.92(11.55)$ & \\
\hline
\end{tabular}

All devices delivered photovoltaic performances higher than 14\%. In general, MAPI based cells led to more satisfying PCE. However, $\mathrm{CH}_{3} \mathrm{NH}_{3} \mathrm{PbI}_{3}$ perovskites (MAPI(2) and MAPI(1)-SOF) gave high hysteresis behavior (Figure 3a,b). Finally, PSC constructed with FAMA gave suitable hysteresis-free $\mathrm{J}-\mathrm{V}$ behavior (Figure $3 \mathrm{c}$ ). The best cell delivered $\mathrm{V}_{\mathrm{OC}}=1.01 \mathrm{~V}, \mathrm{~J}_{\mathrm{SC}}=22.33 \mathrm{~mA} . \mathrm{cm}^{-2}$, $\mathrm{FF}=62.06 \%$ and global $\mathrm{PCE}=14.04 \%$ (the average $\mathrm{PCE}=13.95 \%$ ). 
In comparison with Spiro-OMeTAD based devices, that of iDM1 gave significantly lower photon to electricity conversion outputs. All photovoltaic characteristics of iDM1 are lower accompanied by more important hysteresis behavior. While iDM1 in combination with FAMA perovskite gave hysteresis-free device with $\mathrm{V}_{\mathrm{OC}}$ and $\mathrm{JSC}_{S \mathrm{~V}}$ values approach that of Spiro-OMeTAD, its lower photovoltaic efficiency is due to its lower FF. In comparison to its 3,6-bis(di(4-methoxyphenyl)aminyl) substituted isomer bearing the identical polymerizable side chain (DM1), iDM1 gave significantly improvement in term of photovoltaic performance (PCE of DM1 $=12.26 \%$ ) [17]. We assume that the different in device performance of iDM1 compared to the Spiro-OMeTAD and its 3,6-disubstituted isomer (DM1) is related to the hole transport properties of these materials. This show that 2,7-disubstituted carbazole molecule can be more promising HTM than its more popular 3,6-disubstituted counterpart. However, additional characterizations such as hole mobility measurements, HTM/perovskite thin film fluorescence, optimization of HTM deposition conditions (concentration, additive engineering, etc.) will have to be done in order to explore the full potentiality of this series of hole transporter in perovskite photovoltaics. The chemical conversion of iDM1 into its corresponding polymer will give a complementary comparative study of molecular versus the polymeric materials in term of photovoltaic performance and device stability.

\section{Conclusions}

We have successfully synthetized and characterized a polymerizable carbazole molecular glass. When employed as HTM in PSCs, we obtained photovoltaic performance in the range of $14 \%-15 \%$. Current studies are being focused on the charge transport characterization, synthetizing the full series of compounds and perform their polymerization to prepare the corresponding polymers for comparative studies. This will be subjected to future comparative study of monomer versus its polymeric HTMs in term of the thermal, opto-electro-chemical properties and their influence on the photovoltaic devices performance and stability which is out of the scope of the current study.

Author Contributions: D.M. designed, synthetized and characterized the HTM. M.U. elaborated and characterized photovoltaic devices. T.-T.B., F.G. and T.P. supervised the work. All authors (D.M., M.U., S.P., T.-T.B., T.P., F.G.) participated in analyzing the data. T.-T.B. wrote the manuscript and all other authors commented and approved the final version. All authors have read and agreed to the published version of the manuscript.

Funding: This research received no external funding.

Acknowledgments: M.U. and D.M. acknowledges the Indonesian and Mexican governments for the doctoral scholarships, respectively. We thank Frédéric Dumur (Aix-Marseille Université) for help with HRMS analysis.

Conflicts of Interest: The authors declare no conflict of interest.

\section{References}

1. Mesquita, I.; Andrade, L.; Mendes, A. Perovskite solar cells: Materials, configurations and stability. Renew. Sustain. Energy Rev. 2018, 82, 2471-2489. [CrossRef]

2. Yu, Z.; Sun, L. Recent Progress on Hole-Transporting Materials for Emerging Organometal Halide Perovskite Solar Cells. Adv. Energy Mater. 2015, 5, 1500213. [CrossRef]

3. Leijtens, T.; Giovenzana, T.; Habisreutinger, S.N.; Tinkham, J.S.; Noel, N.K.; Kamino, B.A.; Sadoughi, G.; Sellinger, A.; Snaith, H.J. Hydrophobic Organic Hole Transporters for Improved Moisture Resistance in Metal Halide Perovskite Solar Cells. ACS Appl. Mater. Interfaces 2016, 8, 5981-5989. [CrossRef] [PubMed]

4. Bui, T.-T.; Goubard, F. Matériaux de transport de trous à base de petites molécules organiques pour cellules photovoltaïques hybrides solides. Matér. Tech. 2013, 101, 102. [CrossRef]

5. Bui, T.-T.; Goubard, F. Recent advances in small molecular, non-polymeric organic hole transporting materials for solid-state DSSC. EPJ Photovolt. 2013, 4, 40402. [CrossRef]

6. Shirota, Y. Photo- and electroactive amorphous molecular materials-molecular design, syntheses, reactions, properties, and applications. J. Mater. Chem. 2005, 15, 75-93. [CrossRef] 
7. Liu, X.; Kong, F.; Guo, F.; Cheng, T.; Chen, W.; Yu, T.; Chen, J.; Tan, Z.; Dai, S. Influence of $\pi$-linker on triphenylamine-based hole transporting materials in perovskite solar cells. Dye. Pigment. 2017, 139, 129-135. [CrossRef]

8. Le, T.H.; Dao, Q.-D.; Nghiêm, M.-P.; Péralta, S.; Guillot, R.; Pham, Q.N.; Fujii, A.; Ozaki, M.; Goubard, F.; Bui, T.-T. Triphenylamine-thienothiophene organic charge transport molecular materials: Impact of arylamine substitution position on thermal, photoectrochemical and photovoltaic properties. Chem. Asian J. 2018, 13, 1302-1311. [CrossRef]

9. Chi, W.-J.; Zheng, D.-Y.; Chen, X.-F.; Li, Z.-S. Optimizing thienothiophene chain lengths of D- $\pi-\mathrm{D}$ hole transport materials in perovskite solar cells for improving energy levels and hole mobility. J. Mater. Chem. C 2017, 5, 10055-10060. [CrossRef]

10. Krishna, A.; Sabba, D.; Yin, J.; Bruno, A.; Boix, P.P.; Gao, Y.; Dewi, H.A.; Gurzadyan, G.G.; Soci, C.; Mhaisalkar, S.G.; et al. Facile Synthesis of a Furan-Arylamine Hole-Transporting Material for High-Efficiency, Mesoscopic Perovskite Solar Cells. Chem. A Eur. J. 2015, 21, 15113-15117. [CrossRef]

11. Cho, A.N.; Chakravarthi, N.; Kranthiraja, K.; Reddy, S.S.; Kim, H.S.; Jin, S.H.; Park, N.G. Acridine-based novel hole transporting material for high efficiency perovskite solar cells. J. Mater. Chem. A 2017, 5, 7603-7611. [CrossRef]

12. Ramos, F.J.; Rakstys, K.; Kazim, S.; Gratzel, M.; Nazeeruddin, M.K.; Ahmad, S. Rational design of triazatruxene-based hole conductors for perovskite solar cells. RSC Adv. 2015, 5, 53426-53432. [CrossRef]

13. Berton, N.; Nakar, R.; Schmaltz, B. DMPA-containing carbazole-based hole transporting materials for perovskite solar cells: Recent advances and perspectives. Synth. Met. 2019, 252,91-106. [CrossRef]

14. Sathiyan, G.; Sivakumar, E.K.T.; Ganesamoorthy, R.; Thangamuthu, R.; Sakthivel, P. Review of carbazole based conjugated molecules for highly efficient organic solar cell application. Tetrahedron. Lett. 2016, 57, 243-252. [CrossRef]

15. Bui, T.-T.; Shah, S.K.; Abbas, M.; Sallenave, X.; Sini, G.; Hirsch, L.; Goubard, F. Carbazole-Based Molecular Glasses as Hole-Transporting Materials in Solid State Dye-Sensitized Solar Cells. ChemNanoMat. 2015, 1, 203-210. [CrossRef]

16. Bui, T.-T.; Goubard, F.; Troughton, J.; Watson, T. Simple 3,6-bis(diphenylaminyl)carbazole molecular glasses as hole transporting materials for hybrid perovskite solar cells. J. Mater. Sci. Mater. Electron. 2017, 28, 17551-17556. [CrossRef]

17. Magaldi, D.; Ulfa, M.; Nghiêm, M.P.; Sini, G.; Goubard, F.; Pauporté, T.; Bui, T.T. Hole transporting materials for perovskite solar cells: Molecular versus polymeric carbazole-based derivatives. J. Mater. Sci. 2020, 55, 4820-4829. [CrossRef]

18. Bui, T.-T.; Ulfa, M.; Maschietto, F.; Ottochian, A.; Nghiêm, M.-P.; Ciofini, I.; Goubard, F.; Pauporté, T. Design of dendritic core carbazole-based hole transporting materials for efficient and stable hybrid perovskite solar cells. Org. Electron. 2018, 60, 20-30. [CrossRef]

19. Ulfa, M.; Pauporte, T.; Bui, T.-T.; Goubard, F. Impact of Organic Hole Transporting Material and Doping on the Electrical Response of Perovskite Solar Cells. J. Phys. Chem. C 2018, 122, 11651-11658. [CrossRef]

20. Al Mousawi, A.; Dumur, F.; Garra, P.; Toufaily, J.; Hamieh, T.; Goubard, F.; Bui, T.-T.; Graff, B.; Gigmes, D.; Pierre Fouassier, J.; et al. Azahelicenes as visible light photoinitiators for cationic and radical polymerization: Preparation of photoluminescent polymers and use in high performance LED projector 3D printing resins. J. Polym. Sci. Part A Polym. Chem. 2017, 55, 1189-1199. [CrossRef]

21. Al Mousawi, A.; Lara, D.M.; Noirbent, G.; Dumur, F.; Toufaily, J.; Hamieh, T.; Bui, T.-T.; Goubard, F.; Graff, B.; Gigmes, D.; et al. Carbazole Derivatives with Thermally Activated Delayed Fluorescence Property as Photoinitiators/Photoredox Catalysts for LED 3D Printing Technology. Macromolecules 2017, 50, 4913-4926. [CrossRef]

22. Al Mousawi, A.; Garra, P.; Dumur, F.; Bui, T.-T.; Goubard, F.; Toufaily, J.; Hamieh, T.; Graff, B.; Gigmes, D.; Fouassier, J.; et al. Novel Carbazole Skeleton-Based Photoinitiators for LED Polymerization and LED Projector 3D Printing. Molecules 2017, 22, 2143. [CrossRef] [PubMed]

23. Abdallah, M.; Magaldi, D.; Hijazi, A.; Graff, B.; Dumur, F.; Fouassier, J.; Bui, T.; Goubard, F.; Lalevée, J. Development of New High-Performance Visible Light Photoinitiators Based on Carbazole Scaffold and Their Applications in 3D Printing and Photocomposite Synthesis. J. Polym. Sci. Part A Polym. Chem. 2019, 57, 2081-2092. [CrossRef] 
24. Keruckas, J.; Lygaitis, R.; Simokaitiene, J.; Grazulevicius, J.V.; Jankauskas, V.; Sini, G. Influence of methoxy groups on the properties of 1,1-bis(4-aminophenyl) cyclohexane based arylamines: Experimental and theoretical approach. J. Mater. Chem. 2012, 22, 3015-3027. [CrossRef]

25. Torres, A.; Rego, L.G.C. Surface effects and adsorption of methoxy anchors on hybrid lead iodide perovskites: Insights for spiro-MeOTAD attachment. J. Phys. Chem. C 2014, 118, 26947-26954. [CrossRef]

26. Dierschke, F.; Grimsdale, A.C.; Müllen, K. Efficient Synthesis of 2,7-Dibromocarbazoles as Components for Electroactive Materials. Synthesis. 2003, 16, 2470-2472. [CrossRef]

27. Ulfa, M.; Wang, P.; Zhang, J.; Liu, J.; de Marcillac, W.; Coolen, L.; Peralta, S.; Pauporte, T. Charge Injection and Electrical Response in Low Temperature SnO2-Based Efficient Perovskite Solar Cells. ACS Appl. Mater. Interfaces 2018, 10, 35118-35128. [CrossRef]

28. Im, J.H.; Kim, H.S.; Park, N.G. Morphology-photovoltaic property correlation in perovskite solar cells: One-step versus two-step deposition of CH3NH3PbI 3. APL Mater. 2014, 2, 081510. [CrossRef]

29. Kurtz, S.; Whitfield, K.; TamizhMani, G.; Koehl, M.; Miller, D.; Joyce, J.; Wohlgemuth, J.; Bosco, N.; Kempe, M.; Zgonena, T. Evaluation of high-temperature exposure of photovoltaic modules. Prog. Photovolt. Res. Appl. 2011, 19, 954-965. [CrossRef]

30. Turk, M.J.; Ansari, A.S.; Alston, W.B.; Gahn, G.S.; Frimer, A.A.; Scheiman, D.A. Evaluation of the thermal oxidative stability of polyimides via TGA techniques. J. Polym. Sci. Part A Polym. Chem. 1999, 37, 3943-3956. [CrossRef]

31. Zhang, J.; Sallenave, X.; Bui, T.-T.; Dumur, F.; Xiao, P.P.; Graff, B.; Gigmes, D.; Fouassier, J.P.; Lalevée, J. LED-Induced Polymerization (385, 405, and $455 \mathrm{~nm}$ ) Using Star-Shaped Tris(4-(thiophen-2-yl)phenyl)amine Derivatives as Light-Harvesting Photoinitiators. Macromol. Chem. Phys. 2015, 216, 218-227. [CrossRef]

32. Wang, P.; Shao, Z.; Ulfa, M.; Pauporté, T. Insights into the Hole Blocking Layer Effect on the Perovskite Solar Cell Performance and Impedance Response. J. Phys. Chem. C 2017, 121, 9131-9141. [CrossRef]

33. Wang, P.; Ulfa, M.; Pauporté, T. Effects of Perovskite Monovalent Cation Composition on the High and Low Frequency Impedance Response of Efficient Solar Cells. J. Phys. Chem. C 2018, 122, 1973-1981. [CrossRef]

(C) 2020 by the authors. Licensee MDPI, Basel, Switzerland. This article is an open access article distributed under the terms and conditions of the Creative Commons Attribution (CC BY) license (http://creativecommons.org/licenses/by/4.0/). 